\title{
Evidence-Based Recommendations for the Management of Knee Osteoarthritis: A Consensus Report of the Turkish League Against Rheumatism
}

\author{
Diz Osteoartrit Tedavisinde Kanıta Dayalı Öneriler: \\ Türkiye Romatizma Araştırma ve Savaş Derneği Uzlaşı Raporu
}

Tiraje TUNCER, ${ }^{1}$ Hasan Fatih ÇAY, ${ }^{2}$ Cahit KAÇAR, ${ }^{1}$ Lale ALTAN, ${ }^{3}$ Osman Şahap ATIKK, ${ }^{4}$ Ahmet Turan AYDIN, ${ }^{5}$

F. Figen AYHAN, ${ }^{6}$ Burcu ÇÖREKÇİ YANIK, ${ }^{7}$ Berrin DURMAZ,${ }^{8}$ Nurten ESKIYURT, ${ }^{9}$ Hakan GENÇ, ${ }^{6}$ Yeşim GÖKÇE KUTSAL, ${ }^{10}$ Rezzan GÜNAYDIN,,${ }^{11}$ Simin HEPGÜLER, ${ }^{8}$ Sami HİZMETLİ, ${ }^{12}$ Taciser KAYA, ${ }^{11}$

Yeşim KURTAİş, ${ }^{13}$ Neşe ÖLMEZ,${ }^{14}$ Merih SARIDOĞAN, ${ }^{15}$ Dilşad SINDEL, ${ }^{9}$ Birkan SONEL TUR, ${ }^{13}$

Serap SÜTBEYAZ, ${ }^{16}$ Ömer Faruk ŞENDUR, ${ }^{17}$ Hatice UĞURLU, ${ }^{18}$ Zeliha ÜNLÜ ${ }^{19}$

${ }^{1}$ Department of Physical Medicine and Rehabilitation, Medical Faculty of Akdeniz University, Antalya, Turkey; ${ }^{2}$ Department of Physical Medicine and Rehabilitation and Rheumatology, Antalya Training and Research Hospital Antalya, Turkey; ${ }^{3}$ Department of Physical Medicine and Rehabilitation, Medical Faculty of Uludağ University, Bursa, Turkey; ${ }^{4}$ Department of Orthopaedics and Traumatology, Medical Faculty of Gazi University, Ankara, Turkey; ${ }^{5}$ Department of Orthopaedics and Traumatology, Medical Faculty of Akdeniz University, Antalya, Turkey; ${ }^{6}$ Department of Physical Medicine and Rehabilitation, Ankara Training and Research Hospital Ankara, Turkey; ${ }^{7}$ Department of Physical Medicine and Rehabilitation, Medical Faculty of Fatih University, Ankara, Turkey; ${ }^{8}$ Department of Physical Medicine and Rehabilitation, Medical Faculty of Ege University, İzmir, Turkey; ${ }^{9}$ Department of Physical Medicine and Rehabilitation, İstanbul Medical Faculty of İstanbul University, İstanbul, Turkey; ${ }^{10}$ Department of Physical Medicine and Rehabilitation, Medical Faculty of Hacettepe University, Ankara, Turkey; ${ }^{11}$ Department of Physical Medicine and Rehabilitation, Bozyaka Training and Research Hospital, İmir Turkey; ${ }^{12}$ Department of Physical Medicine and Rehabilitation, Medical Faculty of Cumhuriyet University, Sivas, Turkey; ${ }^{13}$ Department of Physical Medicine and Rehabilitation, Medical Faculty of Ankara University, Ankara, Turkey; ${ }^{14}$ Department of Physical Medicine and Rehabilitation, Atatürk Training and Research Hospital, İzmir, Turkey; ${ }^{15}$ Department of Physical Medicine and Rehabilitation, Cerrahpaşa Medical Faculty of İstanbul University, İstanbul, Turkey; ${ }^{16}$ Department of Physical Medicine and Rehabilitation, Kayseri Training and Research Hospital, Kayseri, Turkey; ${ }^{17}$ Department of Physical Medicine and Rehabilitation, Medical Faculty of Adnan Menderes University, Aydin, Turkey; ${ }^{18}$ Department of Physical Medicine and Rehabilitation, Meram Medical Faculty of Selçuk University, Konya, Turkey; ${ }^{19}$ Department of Physical Medicine and Rehabilitation, Medical Faculty of Celal Bayar University, Manisa, Turkey;

Objectives: Knee osteoarthritis $(\mathrm{OA})$ is a common disease which causes pain, disability and great socioeconomic burden as a result. Turkish League Against Rheumatism (TLAR) initiated a project to prepare national, "evidence-based recommendations for the management of knee osteoarthritis" supported by expertopinion in order to assist the physicians who are interested in knee OA in their daily clinical practice.

Materials and methods: The expert committee was composed of 25 academicians, 23 of whom were physical medicine and rehabilitation (PM\&R) specialists (three also had rheumatology subspeciality) and two were orthopedic surgeons. At the first meeting, the previous guidelines were discussed, and 2008 Osteoarthritis Research Society International (OARSI) recommendations were decided to be taken as the fundamental template for national recommendations. Databases of the Pubmed, Embase, Cochrane, and Turkish Medical Index were used to search the literature, and this was carried out for the period between 2009-2010 for international publications since studies up to 2009 were present in the 2010 OARSI update. No limit was applied for searching of national publications. The selected relevant publications were graded according to evidence level and quality, and were sent to the members who were then asked to suggest propositions according to their experiences, knowledge, and review of the literature. After amalgamation and editing of new proposals, Delphi rounds were started. After five Delphi rounds, the propositions on which the members were in consensus, were discussed with regard to evidence and the "strength of recommendation" was determined by measuring on visual analog scale (VAS) for each proposal at the final meeting.

Results: Nineteen propositions (one for general principles, nine for nonpharmacologic treatments, seven for pharmacologic treatments, and two for surgical treatments) were accepted as the "TLAR Evidence-Based Recommendations for the Management of Knee OA" in consensus as a result of Delphi rounds.

Conclusion: Evidence-based recommendations for the management of knee OA were developed by TLAR for the first time in our country. The recommendations should be updated regularly according to new evidence and insights. It is expected that physicians who are interested in knee OA will benefit greatly from this report in their daily clinical practice. Key words: Knee osteoarthritis; TLAR; treatment guideline.

\begin{abstract}
Amaç: Diz osteoartriti $(O A)$ sık görülen ve neden olduğu ağrı ve sakatlık sonucunda sosyoekonomik yük bindiren bir hastalıktır. Türkiye Romatizma Araştırma ve Savaş Derneği (TRASD) OA tedavisi ile uğraşan hekimlere günlük klinik uygulamalarında yardımcı olmak amacıyla, uzman görüşleri ile desteklenmiş, ulusal "diz osteoartrit tedavisinde kanıta dayalı önerileri" hazırlamak için bir proje başlatmıştır.

Gereç ve yöntemler: Uzmanlar komitesi 23'ü fiziksel tıp rehabilitasyon (FTR) uzmanı (üçü ayrıca romatoloji yan dal uzmanı) ikisi ise ortopedi ve travmatoloji uzmanı olan 25 akademisyenden oluşturulmuştur. İlk toplantıda konu ile ilgili önceden yayınlanmış rehberler üzerinde tartısılmıs ve 2008 Osteoarthritis Research Society International (OARSI) önerilerinin ulusal öneriler için temel şablon olarak kullanılmasına karar verilmiştir. Literatür taraması için Pubmed, Embase, Cochrane ve Türk Tıp Dizini veritabanları kullanılmış olup, uluslararası taramalar için, 2009 yılına kadar yayınlanmış çalışmaların 2010 OARSı güncellemesinde yer almasından dolayı, 2009-2010 yıllarını kapsayacak bir süre kısıtlaması yapılmıştır. Ulusal yayınların taranması için tarih sınırlaması yapılmamıştır. Konuyla ilgili çalıșmalar arasından seçilen makaleler kanıt düzeyi ve kalite açısından derecelendirilmiş, uzmanlar kurulu üyelerine gönderilerek kendilerinden mevcut kanıtlar ve kendi bilgi ve deneyimleri ışığında tedavi önerileri hazırlamaları istenmiştir. Hazırlanan öneriler bir araya getirilmiş, düzeltmeler yapılmış, sonrasında Delphi turları başlatılmıştır. Beş Delphi turu sonunda, üzerinde görüș birliği sağlanan öneriler son toplantıda kanıtlar ışığında tartışılmış ve vizüel analog skala (VAS) üzerinden değerlendirilerek her bir öneri için "öneri gücü" belirlenmiştir.

Bulgular: Delphi turları sonucunda, üzerinde görüş birliği sağlanmış olan 19 öneri (biri genel prensip, dokuzu nonfarmakolojik, yedisi farmakolojik ve ikisi cerrahi tedaviler ile ilgili olmak üzere) "TRASD Diz Osteoartriti Kanıta Dayalı Tedavi Önerileri" olarak kabul edilmiştir.

Sonuç: TRASD tarafından, ülkemizde diz OA'sı ile ilgili ilk kanıta-dayalı tedavi önerileri oluşturulmuştur. Bu önerilerin yeni kanıtlar ve görüşler ışığında düzenli olarak güncellenmesi gerekmektedir. Bu önerilerin, diz OA'sı ile ilgilenen hekimlerin günlük pratiklerine katkısı olacağı beklenmektedir.

Anahtar sözcükler: Diz osteoartriti; TRASD; tedavi rehberi.
\end{abstract}

Correspondence: Tiraje Tuncer, M.D. Akdeniz Üniversitesi Tıp Fakültesi, Fiziksel Tıp ve Rehabilitasyon Anabilim Dalı, Dumlupınar Bulvarı, 07070 Antalya, Turkey. Tel: +90 242 - 2496681 e-mail: tirajetuncer@akdeniz.edu.tr (C)2012 Turkish League Against Rheumatism. All rights reserved. 
Osteoarthritis (OA) is a degenerative joint disease which increases in frequency with age. Pain, disability, and deterioration in quality of life are the main consequences of the disease. It might be accepted as an organ disease since nearly all of the periarticular tissues are involved, even though the main injury is in the cartilage and subchondral bone. Osteoarthritis may be seen in any joint. Involvement of the spine or weight-bearing joints such as the hip and knee may result in more disabling conditions than other parts of the body. The prevalance of symptomatic knee OA was reported as $14.8 \%$ in our country and was more common in females. ${ }^{[1]}$ Bilateral involvement is frequent, and radiologic knee $\mathrm{OA}$ is estimated to be more common. Although many prediposing factors, such as genetic, metabolic, and mechanic disturbances, were blamed, the exact etiopathogenesis of knee OA has yet to be defined. Thus, an absolute cure for OA is not available. A symptomatic approach is widely used along with a variety of treatment options. Several national and international institutions, such as the European League Against Rheumatism (EULAR) and OARSI, have developed management guidelines for OA to assist physicians and patients. ${ }^{[2-5]}$ These guidelines were prepared by evaluating the present treatment options in light of scientific evidence as well as expert opinions. It is anticipated that these guidelines will be modified or adapted and periodically updated for national and regional use, with a perspective toward the social requirements and legal rules of the community. In this context, the Turkish League Against Rheumatism (TLAR) has initiated a project to provide recommendations for the management of several rheumatic diseases.

The objective of this study is to prepare national, evidence-based recommendations in conjunction with expert consensus for the management of knee OA, a disease which has disabling and socioeconomic consequences. These recommendations are intended to provide assistance and updated evidence to physicians who deal with patients with knee OA.

\section{MATERIALS AND METHODS}

In April 2010, TLAR made a general announcement to members by e-mail to determine which experts desired to participate in the development of recommendations for the management of knee $\mathrm{OA}$ and requested for those who were interested to fill out a form consisting of their experience, knowledge, skills, and scientific publications in the field of OA. These forms were then analyzed and an "Expert Committee" was appointed.
Two orthopedic surgeons who have experience on knee OA were also invited to be on the committee. The committee was composed of 25 physicians with 23 physical medicine and rehabilitation (PM\&R) specialists (three had rheumatology subspeciality) and two orthopedic surgeons. A project coordinator and two assistants were assigned to coordinate, search, and review theliterature as well as write the final manuscript. It was decided that they should not be involved in the process of the development of the recommendations. Before the first meeting, coordinators sent existing guidelines and recommendations concerning the management of knee OA to the committee members. At the meeting, the committee discussed the previous recommendations of 2003 European League Against Rheumatism (EULAR), the National Institute for Health and Clinical Excellence (NICE), the American Academy of Orthopedic Surgeons (AAOS), 2008 OARSI recommendations and 2010 OARSI update. ${ }^{[2-6]}$ The committee agreed to select the "2008 OARSI Recommendations for the Management of Osteoarthritis of the Hip and Knee" as a template for our preparation due to its most recent update, comprehensive aspects, and international scope. The committee decided to make necessary modifications with regard to new scientific evidence and their knowledge and experience as well as our national conditions. Experts discussed the methodology related to the literature search and the process for developing recommendations. General principles, nonpharmacologic treatments, pharmacologic treatments, and surgical treatments were chosen as the main topics for the planned recommendations. Then several subtopics under the headings of the main topics were also defined. It was decided that the acceptance level for the 2008 OARSI recommendations would be determined by committee members. In this context, it was planned that the original version of this report would be sent to committee members for assesment on a $0-100 \mathrm{~mm}$ visual analogue scale (VAS), and afterwards, the mean level of acceptance for each proposition would be calculated statistically.

A systematic literature search was performed for only the period between 2009 and 2010 for international publications, since studies up to January 1st, 2009 were present in the 2010 OARSI update. No limit was applied for national literature since pertinent articles could not be found in this way. The databases of Pubmed, Embase, Cochrane, and the Turkish Medical Index were used to search the literature. Reports concerning OA of joints other than the knee 
and those which were not relevant to management were left out of the evaluation. Publications relevant to the management of knee OA were ranked according to the quality of publication and evidence level of the study. Evidence level evaluation was performed according to Table $1 .{ }^{[7]}$ Meta-analyses (MA) and systematic reviews (SR) were graded by using the Oxman-Guyatt index while randomized controlled trials (RCTs) were graded according to the Jadad scale. ${ }^{[8,9]}$ If an MA or RCT existed for any title, any other study with a lower grade was ignored. The report with the highest quality score was selected for evaluation if more than one on the same subject were present. Studies which were not randomized were excluded from quality assessment. Concerning the efficiency and side effects of any treatment regimen, the effect size (small being up to 0.4; moderate 0.4-08; and large if higher than 0.8 ), number needed to treat (NNT), relative risk (RR) and odds ratio (OR) were recorded if available. ${ }^{[10,11]}$

The publications which were evaluated in the context of the above rules were sent to the experts who were asked to suggest 23 propositions according to their experiences, knowledge, and review of literature by taking into account the 2008 OARSI recommendations as the fundamental template. The propositions should cover all the topics defined at the first meeting. A total of 477 propositions covering various categories were sent back by the experts (Table 2). The coordinators eliminated and amalgamated similar or overlapping propositions and sent them back to the members for any necessary revisions. Delphi rounds were then started with 114 propositions. In the first of the Delphi round, the experts were asked to choose 20 propositions from all of the sub-topics. A proposition was accepted if approved by $>60 \%$ of the experts and was rejected if approved by $<20 \%$. Any proposition with an approval of between $20-60 \%$ was included in the next Delphi

\begin{tabular}{|c|c|}
\hline LOE & Explanation \\
\hline Ia & Metaanalysis of randomized controlled trials \\
\hline $\mathrm{Ib}$ & At least one randomized controlled trial \\
\hline IIa & $\begin{array}{l}\text { At least one well-designed controlled study, but } \\
\text { without randomisation }\end{array}$ \\
\hline IIb & At least one well-designed quasi-experimental study \\
\hline III & $\begin{array}{l}\text { At least one non-experimental descriptive study } \\
\text { (comparative, correlation or case-controlled study) }\end{array}$ \\
\hline IV & $\begin{array}{l}\text { Expert committee reports, opinions and/or } \\
\text { experience of respected authorities }\end{array}$ \\
\hline
\end{tabular}

round. After five rounds of Delphi exercises, a total of 19 propositons were selected. These propositions were written with relevant evidence from recent literature and sent back to the experts for reevaluation at the final meeting.

At the final meeting, the experts created the final version of the manuscript with a consensus regarding further additions or removals and minor rewording. Any difference made in any proposition was voted on, and a consensus was reached. At the same meeting, each expert was asked to determine the level of acceptance for each of the 19 propositions on a $0-100 \mathrm{~mm}$ VAS by taking into consideration all evidence and discussions. The mean and 95\% confidence interval (CI) of the acceptance level for each proposition was defined as the strength of recommendation (SOR).

\section{RESULTS}

The expert committee evaluated the 2008 OARSI recommendations on the VAS. As a result, the minimum and maximum levels for accepting each of the 25 propositons were found to be between 51\% (95\% CI 40-62) and 97\% (95\% CI 94-100), respectively.

At the end of five Delphi rounds, 19 propositions (one for general principles, nine for non-pharmacologic treatments, seven for pharmacologic treatments, and two for surgical treatments) were suggested as TLAR evidence-based recommendations for the management of knee OA (Table 3). The level of evidence (LOE), consensus level, and strength of recommendation for these propositions are shown in Table 4.

\begin{tabular}{|lc|}
\hline $\begin{array}{l}\text { Table 2. Initial propositions before the modifications made } \\
\text { by the coordinators }\end{array}$ \\
\hline Category & $\begin{array}{c}\text { Suggested } \\
\text { propositions } \\
\text { (n) }\end{array}$ \\
\hline General principles & 33 \\
Nonpharmacologic management & \\
Education & 29 \\
Daily living activities & 44 \\
Exercises & 28 \\
Physical therapy applications & 57 \\
Assistive \& adaptive devices & 55 \\
Balneotherapy & 25 \\
Complementary \& alternative medicine & 14 \\
Pharmacologic management & \\
Oral and topical drugs & 99 \\
Intraarticular injections & 36 \\
Surgical management & 57 \\
Total & 477
\end{tabular}


Table 3. TLAR evidence-based recommendations for management of knee OA

1. The main goal in the treatment of knee OA should be directed toward controlling pain, preserving and improving the function of joints, providing functional independency, and increasing the quality of life. In order to reach these goals, management of knee OA should contain non-pharmacologic, pharmacologic, and, when necessary, surgical approaches. Treatment should be tailored for each patient individually.

2. Educational programs about the symptoms of the disease, composition, and treatment objectives, designed for individuals and patient groups, may increase the adherence of patients to the therapy. These educational programs should contain lifestyle alterations, joint protection techniques, and diet and exercise programs which would provide weight control.

3. Patients with knee OA should be informed and encouraged to use their joints in a manner that allows the least amount of loading on their joints during their occupational, sports, and daily living activities. They should be educated to make this a principle part of their daily lives. The conditions at their home and office should be designed according to their disease. Patients should be advised to avoid climbing stairs, sitting cross-legged, squatting, kneeling during "namaz (an Islamic prayer)" or doing any other activity which would cause loading and enforcement of knee flexion. Using elevators, sitting without knee flexion during "namaz", and using a Western-style toilet should be advised instead.

4. Age, comorbid diseases, and degree of OA should be taken into consideration when choosing an appropriate exercise program for each individual patient. Patients should be encouraged to do range-of-motion, stretching, isometric, isotonic, balance, proprioception, and aerobic exercises. Aquatic exercises can be planned in concert with the preferences of the patient and physician. The exercise programs should be taught to patients in a manner that they can clearly understand and be able to do on their own. Initially, they should be under supervision, but when the patients are able to do them by themselves, home programs should be started.

5. Physical medicine and rehabilitaion specialists may advise the use of an appropriate walking stick, walker, or similar walking aid after the evaluation of the patients. These devices may decrease the patients' pain levels; therefore, they should be educated regarding the correct use of these devices.

6. In knee OA patients with mild to moderate joint instability, the use of appropriate ortheses may decrease the risk of falling and may help to restore the stability. Each patient should be advised to choose convenient, comfortable, soft-soled shoes. The use of sole plates may help ambulation by decreasing pain in patients with knee OA. The application of a laterally-wedged insole in the shoes may have a symptomatic benefit in patients with medial tibiofemoral OA.

7. Electrotherapeutic agents such as TENS, interferential currents, and diadynamic currents may have beneficial effects on pain, joint function, and quality of life. Superficial and deep heat (ultrasound, short wave diathermy) applications may provide benefits for patients with knee OA who have no active synovitis. Cold application should be advised in the case of synovitis.

8. Neuromuscular electrical stimulation is one of the physical treatment modalities- considered not only for muscle strenghtening but also as an alternative modality for alleviating the pain and functions of patients who are not able to take part in exercise programs.

9. If there is no contraindication, balneotherapy may be recommended for at least two weeks of treatment because of its thermal and nonthermal effects. Patients who are advised to have balneotherapy should be informed about the thermal and mineral aspects of the water of the center that they plan to attend. In addition to this treatment, peloidotherapy may be advised. Balneotherapy may be combined with other physical treatment modalities and exercises by a PM\&R specialist.

10. Complementary treatment options should not be used instead of standard pharmacologic and non-pharmacologic treatments. But if it would be, it should only be used as an additional treatment. Both the beneficial and adverse effects of complementary treatments should be followed carefully.

11. Acetaminophen (maximum $3 \mathrm{~g} /$ day) as an initial treatment may have a mild analgesic effect in patients with knee OA who have a mild/ moderate degree of pain. Alternative treatment options should be considered in case of inadequate response or the presence of severe pain and/or inflammation.

12. Nonselective and selective nonsteroidal anti-inflammatory drugs (NSAIDs) and cyclo-oxygenase 2 (COX-2) inhibitors should be used at their lowest efficacious doses for conditions in which there is moderate to severe pain or synovitis and for situations in which paracetamol is insufficient. Concomitant use of two NSAIDs should be avoided. Gastroprotective agents should be combined with NSAIDs in patients with gastrointestinal complaints. Precaution should be taken with the use of NSAIDs if hypertension exists or renal or hepatic dysfunction are present.

13. Topical NSAIDs or capsaicin can be used in combination with other analgesic and/or anti-inflammatory drugs, or they can be used on their own if patients are unable to take other drugs.

14. Intraarticular glucocorticoid injection, not more than three times a year, can be applied in cases of symptomatic knee OA with signs of inflammation which are unresponsive to other treatment options.

15. Hyaluronic acid injections may be beneficial for patients with mild and moderate $\mathrm{OA}$ who are not overweight, have no instability, and are unresponsive to non-pharmacologic and pharmacologic treatment modalities.

16. Glucosamines and/or chondroitin sulfate may provide symptomatic benefits for patients with knee OA.

17. Administration of weak opioids or narcotic analgesics can be considered for patients with knee OA who are resistant to or have contraindications for treatment with other pharmacologic agents. Treatment with non-pharmacologic modalities should be continued in these patients, and appropriate surgical options should be considered.

18. Osteotomy can be applied in middle-aged, active, unicompartmental knee OA patients with malalignment for the aim of biomechanical correction.

19. Total knee replacement should be considered for patients with advanced knee OA who have resistant pain to pharmacologic and non-pharmacologic treatments and impaired quality of life. Not only the radiologic images but also the degree of pain and functional limitation of patients should be taken into consideration during the course of decision for surgery. 
Table 4. TLAR recommendations with level of evidence, consensus rate and strength of recommendations

1. The main goal in the treatment of knee OA should be directed toward controlling pain, preserving and improving the function of joints, providing functional independency, and increasing the quality of life. In order to reach these goals, management of knee OA should contain non-pharmacologic, pharmacologic, and, when necessary, surgical approaches. Treatment should be tailored for each patient individually.

2. Educational programs about the symptoms of the disease, composition, and treatment objectives, designed for individuals and patient groups, may increase the adherence of patients to the therapy. These educational programs should contain lifestyle alterations, joint protection techniques, and diet and exercise programs which would provide weight control.

3. Patients with knee OA should be informed and encouraged to use their joints in a manner that allows the least amount of loading on their joints during their occupational, sports, and daily living activities. They should be educated to make this a principle part of their daily lives. The conditions at their home and office should be designed according to their disease. Patients should be advised to avoid climbing stairs, sitting cross-legged, squatting, kneeling during "namaz (an Islamic prayer)" or doing any other activity which would cause loading and enforcement of knee flexion. Using elevators, sitting without knee flexion during "namaz", and using a Western-style toilet should be advised instead.

4. Age, comorbid diseases, and degree of OA should be taken into consideration when choosing an appropriate exercise program for each individual patient. Patients should be encouraged to do range-of-motion, stretching, isometric, isotonic, balance, proprioception, and aerobic exercises. Aquatic exercises can be planned in concert with the preferences of the patient and physician. The exercise programs should be taught to patients in a manner that they can clearly understand and be able to do on their own. Initially, they should be under supervision, but when the patients are able to do them by themselves, home programs should be started.

5. Physical medicine and rehabilitaion specialists may advise the use of an appropriate walking stick, walker, or similar walking aid after the evaluation of the patients. These devices may decrease the patients' pain levels; therefore, they should be educated regarding the correct use of these devices.

6. In knee OA patients with mild to moderate joint instability, the use of appropriate ortheses may decrease the risk of falling and may help to restore the stability. Each patient should be advised to choose convenient, comfortable, soft-soled shoes. The use of sole plates may help ambulation by decreasing pain in patients with knee OA. The application of a laterally-wedged insole in the shoes may have a symptomatic benefit in patients with medial tibiofemoral OA.

7. Electrotherapeutic agents such as TENS, interferential currents, and diadynamic currents may have beneficial effects on pain, joint function, and quality of life. Superficial and deep heat (ultrasound, short wave diathermy) applications may provide benefits for patients with knee OA who have no active synovitis. Cold application should be advised in the case of synovitis.

8. Neuromuscular electrical stimulation is one of the physical treatment modalities- considered not only for muscle strenghtening but also as an alternative modality for alleviating the pain and functions of patients who are not able to take part in exercise programs.

9. If there is no contraindication, balneotherapy may be recommended for at least two weeks of treatment because of its thermal and non-thermal effects. Patients who are advised to have balneotherapy should be informed about the thermal and mineral aspects of the water of the center that they plan to attend. In addition to this treatment, peloidotherapy may be advised. Balneotherapy may be combined with other physical treatment modalities and exercises by a PM\&R specialist.

10. Complementary treatment options should not be used instead of standard pharmacologic and nonpharmacologic treatments. But if it would be, it should only be used as an additional treatment. Both the beneficial and adverse effects of complementary treatments should be followed carefully.

11. Acetaminophen (maximum $3 \mathrm{~g} /$ day) as an initial treatment may have a mild analgesic effect in patients with knee OA who have a mild/moderate degree of pain. Alternative treatment options should be considered in case of inadequate response or the presence of severe pain and/or inflammation.

12. Nonselective and selective nonsteroidal anti-inflammatory drugs (NSAIDs) and cyclo-oxygenase 2 (COX-2) inhibitors should be used at their lowest efficacious doses for conditions in which there is moderate to severe pain or synovitis and for situations in which paracetamol is insufficient. Concomitant use of two NSAIDs should be avoided. Gastroprotective agents should be combined with NSAIDs in patients with gastrointestinal complaints. Precaution should be taken with the use of NSAIDs if hypertension exists or renal or hepatic dysfunction are present.

13. Topical NSAIDs or capsaicin can be used in combination with other analgesic and/or anti-inflammatory drugs, or they can be used on their own if patients are unable to take other drugs.

14. Intraarticular glucocorticoid injection, not more than three times a year, can be applied in cases of symptomatic knee OA with signs of inflammation which are unresponsive to other treatment options.

15. Hyaluronic acid injections may be beneficial for patients with mild and moderate $\mathrm{OA}$ who are not overweight, have no instability, and are unresponsive to non-pharmacologic and pharmacologic treatment modalities.

16. Glucosamines and/or chondroitin sulfate may provide symptomatic benefits for patients with knee OA.

17. Administration of weak opioids or narcotic analgesics can be considered for patients with knee $\mathrm{OA}$ who are resistant to or have contraindications for treatment with other pharmacologic agents. Treatment with non-pharmacologic modalities should be continued in these patients, and appropriate surgical options should be considered.

18. Osteotomy can be applied in middle-aged, active, unicompartmental knee OA patients with malalignment for the aim of biomechanical correction.

19. Total knee replacement should be considered for patients with advanced knee OA who have resistant pain to pharmacologic and non-pharmacologic treatments and impaired quality of life. Not only the radiologic images but also the degree of pain and functional limitation of patients should be taken into consideration during the course of decision for surgery.

$\begin{array}{lll}\text { IV } & 77.3 & 96.8(93-100) \\ \text { Ib, III } & 77.3 & 95.7(94-98) \\ \text { III, IV } & 63.6 & 94.0(91-97)\end{array}$




\section{General Principles}

1. The main goal in the treatment of knee OA should be directed toward controlling pain, preserving and improving the function of joints, providing functional independency, and increasing the quality of life. In order to reach these goals, management of knee $\mathrm{OA}$ should contain non-pharmacologic, pharmacologic, and, when necessary, surgical approaches. Treatment should be tailored for each patient individually.

The daily clinical practice for the management of knee OA is a combination of pharmacologic and nonpharmcologic treatment options. The main goal of all these approaches is to decrease pain and ameliorate the functional capacity of the patients. This is a generally accepted proposition although there is no clinical trial evidence to support it. It was included in all previously published guidelines eventhough the LOE is IV. ${ }^{[2-5]}$ Similarly, the majority of the experts voted in favor of accepting this recommendation during the Delphi tours of our study, and the SOR was $96.8 \%$ (95\% CI 93-100).

\section{Non-Pharmacologic Treatment}

2. Educational programs about the symptoms of the disease, composition, and treatment objectives, designed for individuals and patient groups, may increase the adherence of patients to the therapy. These educational programs should contain lifestyle alterations, joint protection techniques, and diet and exercise programs which would provide weight control.

The instructional programs, which include lifestyle alteration, joint protection principles, and suggestions for weight reduction, are contained in the main guidelines for patients with knee OA. These programs can be given individually or as group education, the latter being less expensive. Group education followed up by home exercise programs has been shown to restore functional capacity and improve pain levels (LOE Ib). ${ }^{[12]}$ Obesity is considered to be a risk factor for symptomatic knee OA. Each 3 or $4 \mathrm{~kg} / \mathrm{m}^{2}$ increase in body mass index (BMI) doubles the risk of OA. ${ }^{[13]}$ Weight reduction was strongly recommended in previous guidelines, even though controversy existed about the relationship between weight reduction and clinical symptoms. ${ }^{[2-5]}$ In a recently published report, a $10 \%$ reduction of weight in obese individuals showed significant improvement in the symptoms of knee OA (LOE III). ${ }^{[14]}$ Bliddal et al. ${ }^{[15]}$ reported that an $11 \%$ weight reduction in overweight patients provided a small but significant degree of reduction in pain associated with symptomatic knee OA (LOE Ib). Thus, an education program that includes weight control for the patients has great importance. The experts strongly recommended this proposition (SOR 95.7\%, 95\% CI 94-98).

3. Patients with knee $\mathrm{OA}$ should be informed and encouraged to use their joints in a manner that allows the least amount of loading on their joints during their occupational, sports, and daily living activities. They should be educated to make this a principle part of their daily lives. The conditions at their home and office should be designed according to their disease. Patients should be advised to avoid climbing stairs, sitting cross-legged, squatting, kneeling during "namaz (an Islamic prayer)" or doing any other activity which would cause loading and enforcement of knee flexion. Using elevators, sitting without knee flexion during "namaz", and using a Western-style toilet should be advised instead.

Modification of daily living activities is an important component of non-pharmacologic treatment options for management of knee OA. Additionally, patients should learn joint protection principles for when they do occupational activities or participate in sports. Activities which put pressure on the knee might aggrevate symptoms in a dose/response manner. ${ }^{[16]}$ Squatting or bending of the knee and similar activities were reported to possibly contribute to the development of symptomatic knee OA in both genders (OR was 2.5\%, 95\% CI 1.4-4.7; and $2.2 \%$ 95\% CI 1.2-3.8 for females and males, respectively). Particularly with obesity and load lifting activities, the risk was even higher. ${ }^{[13,16]}$ In an epidemiological survey, no association was found between "namaz" and symptomatic knee OA (LOE III). ${ }^{[1]}$ More comprehensive investigations concerning these issues are needed. In light of present scientific data, to avoid knee flexion, using alternative positions during "namaz" might be more beneficial (LOE IV). Patients should also be instructed to modify their sitting positions along with their use of stairs and the toilet, although there is no adequate evidence to support this approach. ${ }^{[16]}$ This propositon was strongly recommended (SOR 94\%, 95\% CI 91-97).

4. Age, comorbid diseases, and degree of $\mathrm{OA}$ should be taken into consideration when choosing an appropriate exercise program for each individual patient. Patients should be encouraged to do rangeof-motion, stretching, isometric, isotonic, balance, proprioception, and aerobic exercises. Aquatic 
exercises can be planned in concert with the preferences of the patient and physician. The exercise programs should be taught to patients in a manner that they can clearly understand and be able to do on their own. Initially, they should be under supervision, but when the patients are able to do them by themselves, home programs should be started.

Exercise protocols should be tailored according to the clinical aspects and individual needs of each patient. The importance of exercise treatments has been emphasized in previous recommendations and guidelines. $^{[2-6]}$ In an RCT, no difference between behavioral activity and normal exercise therapy was found in the long-term primary outcome measures of $\mathrm{OA}^{\left[{ }^{[17]}\right.}$ It was reported that progressive resistive exercises improved physical acitivity and reduced pain in patients with knee OA (LOE Ib). ${ }^{[18]}$ Tai Chi exercises might be considered as an optional treatment choice since they are safe and effective on pain and function, although there is no significant scientific evidence to prove its benefits. ${ }^{[19]}$ Aquatic exercises were not deemed to be superior when compared with other types of exercises, but they might be preferred due to less pain occurring after exercise. ${ }^{[20]}$ According to the results of an RCT which compared the effects of loading and non-loading exercises, simple flexionextension exercises for an eight-week period provided significant functional improvement for patients using either type of exercises; however, the beneficial effect in position sensation was shown only in the group doing the loading exercises (LOE Ib). ${ }^{[21]}$ In another RCT, simple strengthening exercises designed as a home program provided significant pain relief and functional improvement in long-term follow-up. As a result of this study, weight reduction was found to have no benefit on pain, but it improved depression (LOE Ib). ${ }^{[22]} \mathrm{A}$ pilot study was performed in our country concerning the results of Pilates exercises which were designed as group and home exercise programs. This study showed that these exercises led to improvement in many clinical parameters, especially when performed as group therapy. ${ }^{[23]}$ Lin et al. ${ }^{[24]}$ reported significant improvement in pain and functional Western Ontario and McMaster Universities Osteoarthritis Index (WOMAC) scores in an RCT in which strengthening and proprioceptive exercises without loading were compared (LOE Ib). Progressive resistive training programs were found to have beneficial effects on physical activities, especially in those patients with early OA. ${ }^{[18]}$ Significant improvement in pain and functional capacity was shown when performing concentric- eccentric isokinetic training for the quadriceps muscle (LOE Ib). ${ }^{[25,26]}$ There are many kinds of exercises for the treatment of knee OA. A detailed evaluation of the patient along with an appropriate choice of exercise with respect to the patient's needs are crucial. The LOE was good, and the SOR was high for this proposition (SOR 97\%; CI 95-98).

\section{Physical medicine and rehabilitaion specialists} may advise the use of an appropriate walking stick, walker, or similar walking aid after the evaluation of the patients. These devices may decrease the patients' pain levels; therefore, they should be educated regarding the correct use of these devices.

Patients with knee OA may have difficulty in walking due to a variety of factors. Patients generally transmit almost all body weight to the medial compartment of the knee joint. Reduction of the loading over this site may be an important treatment goal. Use of walking sticks may be recommended for this purpose. A study which evaluated the effect of using walking sticks revealed that for patients who used them for two months, a small but significant amount of improvement occurred in their pain and function (effect sizes $0.18,95 \%$ CI $-0.42-0.87$ and $0,13,95 \%$ CI $-0.11-0.42$, respectively) (LOE Ib). ${ }^{[27]}$ If involvement is unilateral, sticks or crutches should be used contralaterally. In case of bilateral involvement, simple walkers or walkers with rollers should be the preference. This proposition has no supportive evidence at the RCT level, but our experts strongly recommended it, and the SOR was high $(96.4 \%, 95 \%$ CI 95-98).

6. In knee $\mathrm{OA}$ patients with mild to moderate joint instability, the use of appropriate ortheses may decrease the risk of falling and may help to restore the stability. Each patient should be advised to choose convenient, comfortable, soft-soled shoes. The use of sole plates may help ambulation by decreasing pain in patients with knee $\mathrm{OA}$. The application of a laterallywedged insole in the shoes may have a symptomatic benefit in patients with medial tibiofemoral $O A$.

This proposition is also present in the 2008 OARSI recommendations. Based on a brace study, the authors concluded that if a brace or sleeve application was compared with medical therapy alone, there was limited evidence of additional beneficial effects on pain and function, with the brace being more effective than sleeve (LOE Ia). ${ }^{[2]}$ In an SR which was published after this report, non-randomized trials were also analyzed. ${ }^{[28]}$ It was concluded that compressive 
loading over the medial tibial compartment might be decreased, proprioception might be improved, and the isokinetic power of the quadriceps muscle might be increased by using a valgus brace (LOE III). A shortto-medium period of using the valgus brace might provide pain relief and improve quality of life, but the effect range of this device is variable, and it is difficult and uncomfortable to use.

In a study performed in our country, the authors reported that medial taping of the patella was superior to other medical therapies in patellofemoral OA (LOE III). ${ }^{[29]}$

Recommending the use of appropriate shoes is not supported by evidence in controlled trials. Instead, it was recommended based on expert opinions (LOE IV).

Laterally-wedged insole application for medial tibiofemoral OA was recommended by many guidelines, and there are many trials concerning this issue. Two RCTs were published after the 2010 update of the OARSI recommendations. In the first trial performed in our country, the effects of laterally-wedged insole application on pain and function was evaluated in patients with knee OA. As a result, it was found that it was superior to medical therapy consisting of analgesics and exercise (LOE Ib). ${ }^{[30]}$ In the other RCT, the effects of laterally-wedged insole application was compared with the use of the valgus brace. Both treatment modalities led to a significant reduction in pain, but neither was superior to the other (LOE Ib). ${ }^{[31]}$ The strength of recommendation was moderate for this proposition (SOR 86.4\%, 95\% CI 80-93).

7. Electrotherapeutic agents such as TENS, interferential currents, and diadynamic currents may have beneficial effects on pain, joint function, and quality of life. Superficial and deep heat (ultrasound, short wave diathermy) applications may provide benefits for patients with knee $\mathrm{OA}$ who have no active synovitis. Cold application should be advised in the case of synovitis.

Physical treatment modalities are widely used and preferred by patients with knee OA. Superficial and deep heaters along with analgesic currents may be the only treatment options, especially for elderly patients who are potentially intolerant to drugs. Physical modalities are recommended by all guidelines for the management of knee OA. ${ }^{[2-5]}$ The number of RCTs regarding the effects of these agents is not sufficient. In a study performed in our country, a combination of hot pack, transcutaneous electrical nerve stimulation (TENS), therapeutic ultrasound, quadriceps strengthening exercises, and diclofenac was compared with the use of diclofenac alone. After completion of a 10-day session, painless walking distance and daily living activities showed greater improvement in the group having a combination of physical agents (LOE Ib). ${ }^{[32]}$ In another study, the effects of a combination of ultrasound and TENS combined with exercises was found to be superior to exercise therapy alone on the restoration of balance (LOE Ib). ${ }^{[33]}$ The 2008 OARSI reccomendations and many other guidelines have recommended the use of TENS for knee OA. The efficiency of TENS by itself on pain and joint function in knee OA was evaluated in an SR and was found to be insignificant. ${ }^{[34]}$ The heterogeneity and inadequate number of patients within the evaluated trials were the weaknesses of this SR, and the necessity for well-designed trials was emphasized. According to a recent study, an RCT with a combination of exercises, hot compresses, and TENS created better results on pain and quality of life scores than the same combination with sham TENS application (LOE Ib). ${ }^{[35]}$ Transcutaneous electrical nerve stimulation, diadynamic currents or interferential currents are thought to produce analgesia. These modalities were investigated in combination with exercise and/or heat applications in general. Therefore, the pure efficiency of these currents could not been estimated individually. However, combination therapy is used in daily practice.

Superficial and deep heating modalities are widely used in the management of knee OA. According to the 2010 OARSI update, application of any thermal modality in patients with knee OA is also recommended in the majority of guidelines. ${ }^{[6]}$ Mechanical vibrations, continous passive motion, and thermal applications in combination with other treatments were reported to provide significant improvement in pain and functions (LOE Ib). ${ }^{[36]}$

The application of therapeutic ultrasound was found to be effective for providing symptomatic and functional improvements in knee $\mathrm{OA}$ in two MA, but the heterogeneity of the methods and weaknesses in the level of evidence of evaluated trials created difficulty in predicting the effect size of this modality (LOE Ia). ${ }^{[37,38]}$ In a study performed in our country, the authors showed that an exercise program combined either with ultrasound or short-wave diathermy had significant beneficial effects on pain and function. However, the low number of subjects and lack of a control group were limitations of this study (LOE III). ${ }^{[39]}$ The application of a 10-session 
therapeutic ultrasound was compared with sham in another RCT, and a significant reduction in pain scores (48\%) together with significant improvements in the total WOMAC score and 50-meter walking time were found (LOE Ib). ${ }^{[40]}$

Pulsed electromagnetic field treatment for knee OA was evaluated in a small trial, and a significant improvement in WOMAC scores was reported (LOE Ib). ${ }^{[41]}$ Based on nine trials with 483 patients, the authors concluded that pulsed electromagnetic field therapy improved pain and stiffness scores in patients with knee OA, but not significantly. In contrast, the daily living activities and functional scores improved significantly (LOE Ia). ${ }^{[42]}$ It was shown that pulsed electromagnetic field therapy was not superior to conventional physical therapy (LOE Ib). ${ }^{[43]}$ Pulsed electromagnetic field treatment did not exist in guidelines published before the 2010 update of the OARSI recommendations. ${ }^{[6]}$ In summary, the beneficial effect of pulsed electromagnetic field therapy is evident with respect to function functions, but it is not as clear considering on pain.

Iontophoresis and phonophoresis may improve pain and functional activities. Applications of ibuprofen iontophoresis and phonophoresis were found to significantly improve pain and functional levels when compared with the initial findings, but no difference was evident between the two modalities. ${ }^{[4,45]}$ This proposition consisted of a variety of physical agents with different levels of evidence, and our experts recommended it strongly (SOR 96.5\%, 95\% CI 94-99).

8. Neuromuscular electrical stimulation is one of the physical treatment modalities- considered not only for muscle strenghtening but also as an alternative modality for alleviating the pain and functions of patients who are not able to take part in exercise programs.

In studies in which the effects of neuromuscular electrical stimulation and isometric exercise of the quadriceps muscle were compared, it was shown that both modalities provide improvement in pain and function related to the initial level. However, the patients who received electrical stimulation had greater improvement, especially in walking capacity. ${ }^{[46-48]}$ In these studies, other treatment modalities, such as superficial heating and TENS, were also used. An enlargement in the mass and an increase in the perfusion of the quadriceps muscle were demonstrated by computed tomography (CT) and scintigraphy (LOE III). Neuromuscular electrical stimulation is widely used in the early period after an arthroplasty operation. In an MA, it was mentioned that the evidence level of studies related to electrical stimulation was low, so the effect should be accepted with caution (LOE Ia). ${ }^{[49]}$ The SOR of this proposition was $88,1 \%$ (95\% CI 82-94).

9. If there is no contraindication, balneotherapy may be recommended for at least two weeks of treatment because of its thermal and non-thermal effects. Patients who are advised to have balneotherapy should be informed about the thermal and mineral aspects of the water of the center that they plan to attend. In addition to this treatment, peloidotherapy may be advised. Balneotherapy may be combined with other physical treatment modalities and exercises by a PM\&R specialist.

Balneotherapy and mineral water baths are nonpharmacologic options that have been used for the treatment of knee OA for a long time. In an SR (LOE Ia), the results of nine RCTs with a total of 493 patients who completed 10-24 weeks of treatment duration were evaluated. It was concluded that the scores of pain and functional capacity were improved, and this improvement lasted for 24 weeks. It was also decided that balneotherapy can be considered as a safe and effective option when used as part of a multidisciplinary approach for the management of knee OA. ${ }^{[50]}$ Forestier et al. ${ }^{[51]}$ reported that a three-week period of spa treatment combined with a pharmacologic and home exercise program was superior to conventional treatments and exercise alone at the end of sixth month, and it was better tolerated (LOE Ib). A trial performed in Gönen/Balıkesir demonstrated that 20 minutes of treatment duration applied twice daily for two weeks improved walking time as well as the general health quality in patients with knee OA (LOE III). ${ }^{[52]}$ Any patient directed to balneotherapy should be informed concerning its potential effects, especially the "thermal crisis", of this treatment option. The presence of a PM\&R specialist in balneotherapy centers may decrease such potential adverse events. Additionally, a combination of balneotherapy with physical agents and exercises can also be performed (SOR was 91.2, 95\% CI 87-95).

10. Complementary treatment options should not be used instead of standard pharmacologic and nonpharmacologic treatments. But if it would be, it should only be used as an additional treatment. Both the beneficial and adverse effects of complementary treatments should be followed carefully. 
Acupuncture, which has been accepted as an alternative or complemantory treatment option, was considered as a separate proposition in the 2008 OARSI recommendations, but the SOR was low (59\%; 95\% CI 47-71). ${ }^{[2]}$ Acupuncture was not mentioned in the NICE and AAOS guidelines. ${ }^{[4,5]}$ The beneficial effects of acupuncture were shown in sham-controlled studies, but the level of evidence and the quality of evaluated trials were not sufficient (LOE Ia). ${ }^{[53]}$ The clinical effectiveness of acupuncture application might vary depending on the technique used by the person performing, and some of the neurophysiologic alterations attributed to acupuncture might be considered to be a placebo effect. ${ }^{[54]}$ The SOR of this proposition was $93.6 \%$, (95\% CI 89-91).

\section{Pharmacologic Treatment}

11. Acetaminophen (maximum 3 g/day) as an initial treatment may have a mild analgesic effect in patients with knee $\mathrm{OA}$ who have a mild/moderate degree of pain. Alternative treatment options should be considered in case of inadequate response or the presence of severe pain and/or inflammation.

Acetaminophen was accepted as the first drug of choice in the treatment of knee OA by many of the guidelines. ${ }^{[2-5]}$ In the updated 2010 OARSI recommendations, as a result of a cumulative metaanalytic evaluation, the effect size of analgesia provided by acetaminophen was found to be low but significant. In addition, it was concluded that acetaminophen had no effect on stiffness and function of the joint (LOE Ia). ${ }^{[6]}$ There is controversy concerning the recommended acetaminophen dose. Four grams per day was suggested by the 2008 OARSI recommendations. ${ }^{[2]}$ According to more recent trials, consumption of acetaminophen at a dose higher than $3 \mathrm{~g} /$ day might be associated with a high risk of gastrointestinal complications, and long-term consumption could cause hypertension and impairment in renal functions. ${ }^{[55,56]}$ In our recommendations, the suggested maximum dose for acetaminophen is $3 \mathrm{~g} /$ day. Using slow-release acetaminophen might increase the compliance (LOE III). ${ }^{[57]}$ The SOR was $90.6 \%$ (95\% CI 83-98).

12. Nonselective and selective nonsteroidal antiinflammatory drugs (NSAIDs) and cyclo-oxygenase 2 (COX-2) inhibitors should be used at their lowest efficacious doses for conditions in which there is moderate to severe pain or synovitis and for situations in which paracetamol is insufficient. Concomitant use of two NSAIDs should be avoided. Gastroprotective agents should be combined with NSAIDs in patients with gastrointestinal complaints. Precaution should be taken with the use of NSAIDs if hypertension exists or renal or hepatic dysfunction are present.

When symptomatic knee OA has been unresponsive to paracetamol, NSAIDs have been recommended by almost all of the guidelines or recommendations. According to previous investigations, the effect size for the analgesia provided by NSAIDs was reported to be between 0.20-0.29 (LOE Ia). ${ }^{[6]}$ In an RCT (LOE Ib), the analgesic effect of diflunisal was evaluated and was reported to be superior to a placebo. ${ }^{[58]}$ After the 2010 update, three RCTs concerning new NSAIDs were published (LOE Ib). In the first RCT, S-adenosylmethionine and nabumetone were compared in an eight-week study. With both drugs, a significant reduction in pain scores was found when compared with the initial findings, with no difference between the two drugs. ${ }^{[99]}$ In the second trial, the effects of naproxcinod were compared with naproxen and placebo. ${ }^{[60]}$ Naproxcinod and naproxen provided significant improvement in pain and function over the placebo. The systemic blood pressure was found to be higher among patients using naproxen while there was not any difference between the placebo and naproxcinod. In a trial (LOE IIb), patients who were candidates for total knee replacement (TKR) surgery were treated either with celecoxib or indomethacin for a four-week period prior to the procedure, and cartilage and synovial samples were evaluated after the surgery. ${ }^{[6]]}$ Proteoglycan synthesis was found to be significantly increased among celecoxib users but not in the indomethacin and control groups. Prostaglandin E 2 (PGE 2) levels were found to be lower in the patients who used either of the drugs when compared with the controls. The indomethacin and celecoxib groups had lower levels of interleukin-1beta (IL-1 $\beta$ ) while the latter group also had lower levels of tumor necrosis factor-alpha (TNF- $\alpha$ ). In order to prevent the potential adverse effects of NSAIDs on the gastrointestinal system, concomittant use of misoprostol or proton pump inhibitors were included in almost all of the guidelines. The use of COX-2 specific inhibitors was also recommended for patients with a gastrointestinal risk (LOE Ib). ${ }^{[2-5]}$ In our country, however, COX-2 inhibitors are not officially permitted. On the other hand, potential adverse cardiovascular events related to COX-2 inhibitors have been demonstrated by several reports, with the presence of ischemic heart disease or history of stroke being defined as contraindications for COX-2 inhibitors. ${ }^{[6]}$ These drugs should be used 
with caution in patients with hypertension, diabetes mellitus, hyperlipidemia, peripheral arterial disease, or in those who smoke or have other similar risk factors. This proposition was strongly recommended (SOR 95.8\%, 95\% CI 94-98).

13. Topical NSAIDs or capsaicin can be used in combination with other analgesic and/or antiinflammatory drugs, or they can be used on their own if patients are unable to take other drugs.

Topical NSAIDs are widely used by patients with knee $\mathrm{OA}$, and their use is recommended by many guidelines, including the 2008 OARSI recommendations. ${ }^{[2-5]}$ The effects of these drugs on pain and stiffness were found to be moderate and superior to placebo, but analyzed trials were highly heterogenous (LOE Ia). ${ }^{[2]}$ The adverse event occurrance was not different than for the placebo. Capsaicin is a lipophylic alkaloid extracted from chilli peppers. It is considered to be effective over nociceptive receptors. It is recommended to be applied topically four times per day over the painful joint. No significant side effects, other than itching or a burning sensation on the site of application, have been reported. The SOR was $95.5 \%$ (95\% CI 92-99) for this proposition.

14. Intraarticular glucocorticoid injection, not more than three times a year, can be applied in cases of symptomatic knee $\mathrm{OA}$ with signs of inflammation which are unresponsive to other treatment options.

Intraarticular glucocorticoid administration has been widely used for a long period of time for the management of knee OA. It has been recommended by a variety of guidelines, including the 2008 OARSI recommendations. ${ }^{[2-5]}$ The effect size was reported as $0.58(95 \%$ CI $0.34-0.82)$ with intraarticular administrations from the first to the third weeks. The NNT was 5 (95\% CI 3-38) (LOE Ia). ${ }^{[62]}$ The beneficial effects of intraarticular glucocorticoids seem to dissappear by the end of the fourth week. No significant adverse effects have been reported, Their use has been recommended especially for patients with inflammatory findings. Patients should be instructed not to overuse their joints after the injection in order to prevent accelerated progression of the disease. The evidence level was high, and our experts supported this proposition strongly (SOR 97\%, 95\% CI 95-99).

15. Hyaluronic acid injections may be beneficial for patients with mild and moderate $\mathrm{OA}$ who are not overweight, have no instability, and are unresponsive to non-pharmacologic and pharmacologic treatment modalities.
Intraarticular administration of hyaluronic acid (IHA) is used extensively for treatment of knee OA, despite controversies regarding its efficiency. This proposition did not exist in the NICE guideline, and the controversies were emphasized in the AAOS. ${ }^{[4,5]}$ Zhang et al. ${ }^{[6]}$ evaluated the trials related to IHA until 2009, and they mentioned that the studies were done with different formulations, performed weekly for three to five times weekly, and compared either with placebo or glucocorticoids. The efficiency was prompted at the first through the fourth weeks of treatment (LOE Ia). The effect sizes for pain relief along with improvement in function and stiffness were found to be moderate when compared with the placebo $(0.60,95 \%$ CI $0.35-0.87,0.61,95 \%$ CI $0.37-0.83$ and $0.54,95 \%$ CI $0.17-1.26$, respectively). The NNT was 7 (95\% CI 3-119). They also emphasized that the trials were heterogenous. When an elimination was carried out according to the Jadad quality score, no significant difference was found in the pain scores. Pain relief occurred earlier in the glucocorticoid group (2-4 weeks) while requiring much more time in the IHA group (5-13 weeks). There is no MA concerning the effects of IHA published after 2009. According to an RCT, an application of $6 \mathrm{ml}$ of hylan GF (instead of weekly injections) provided pain relief at the $26^{\text {th }}$ week of administration (LOE Ib). No difference was reported between these two applications with respect to adverse events. ${ }^{[63]}$ In another study, the effects of intraarticular administrations of glucocorticoids and IHA were compared, and no significant clinical differences were found. ${ }^{[64]}$ The synovial fluid examination revealed a significant increase in the levels of sodium hyaluronate (Na-HA) and a significant decrease in the levels of matrix metalloproteinase- 9 in the patients treated with IHA. It was suggested that IHA not only had a protective effect on articular cartilage but also an inhibitor effect on catabolism (LOE III). In a one-year follow-up study, after five consecutive weeks of IHA administration in 337 subjects, pain, function, and the need for paracetamol consumption were evaluated at three, six, nine and 12 months. The results were found to be no better than placebo (LOE Ib). ${ }^{[55]}$ There have been a number of trials performed in our country on this subject. In one of these, five consecutive weeks of IHA administration in patients with knee OA was evaluated, and the results were also found to be no better than placebo (LOE Ib). ${ }^{[6]}$ In the second trial, IHA administration was performed for patients with synovitis, and the results at the end of first year were found to be better than placebo. ${ }^{[67]}$ In the patients who had been treated with IHA, short-term improvement 
in proprioception and isokinetic muscle strength along with significant improvement in function were also reported (LOE Ib) ${ }^{[68]}$ In brief, the trials concernig the effects of IHA are heterogenous. Their application may provide a beneficial effect by selecting appropriate patients. The SOR was $88.8 \%$, (95\% CI 83-95).

16. Glucosamines and/or chondroitin sulfate may provide symptomatic benefits for patients with knee OA.

Glucosamine sulphate (GS) and chondroitin sulphate (CS) are complex sugars within the natural structure of articular cartilage. Both molecules are prepared for oral consumption and partially absorbed in the small intestine. It was reported that they could be detected in synovial fluid as well as serum after administration. ${ }^{[69]}$ They have been used by patients with knee OA extensively and have been preferred by many physicians interested in OA, particularly in the last 10 years. The recommended dose for GS is $1500 \mathrm{mg} / \mathrm{day}$ for six weeks with a one-week break, and it should be stopped if there is no response at the end of six months. There are a number of studies concerning the use of GS and CS, but their efficacy is still controversial. It is also not clear whether these agents modify the structure of articular cartilage or not. While administration of GS was recommended in several guidelines concerning the management of knee OA, CS existed only in a few of them. Neither of the molecules was recommended in the NICE and AAOS guidelines. ${ }^{[3,4]}$ The use of GS and CS in knee OA, which was in the 2008 OARSI recommendations, was dependent on a Cochrane review published in 2005, but variability in the formulations were not taken into account. ${ }^{[70]}$ In the 2010 update of the OARSI recommendations, the therapeutic effects of GS and glucosamine hydrochloride (GH) were analyzed separately. ${ }^{[6]}$ The authors suggested that the efficiency of GH on pain was small and statistically insignificant. The studies related to GS were heterogenous, and when they were evaluated according to quality, the effect size for pain was found to also be small but significant $(0.29,95 \%$ CI $0.0003-0.57)$ (LOE Ia). The heterogeneity of the studies was a major problem. The studies concerning the effects of CS were also heterogenous. The results of these studies, if analyzed in accordance with quality assesment, indicated that the effect on pain was small and insignificant. No significant adverse event was reported $(\mathrm{RR} / \mathrm{OR}=0.97$ and 0.99) (LOE Ia). ${ }^{[6]}$ In two MAs, the long-term effects of GS and CS were evaluated based on the modification of the structure and progression of the joints. ${ }^{[71,72]}$ In one MA based on six RCTs, Lee et al. ${ }^{[71]}$ analyzed a total of 1502 patients and concluded that no significant differences were found in joint space narrowing by the end of the first year in patients who used GS, and a small to moderate difference was observed in the third year of treatment (effect size $0.43,95 \%$ CI $0.24-0.63$ ) (LOE Ia). Similarly, patients who used CS had a small but significant difference in joint space by the end of the second year (effect size $0.26,95 \%$ CI $0.13-0.39$ ). As a result of this MA, the authors suggested that administration of GS for three years and CS for two years might delay the radiologic progression of the disease. ${ }^{[71]}$ In the other MA, the results of two RCTs were analyzed, and the authors concluded that a small but significant difference in joint space narrowing was found in the patients taking CS $800 \mathrm{mg} /$ day for two years when compared with placebo (effect size 0.23 , 95\% CI 0.11-0.35) ${ }^{[72]}$ In one of the studies from this MA, Kahan et al. ${ }^{[73]}$ suggested that pain relief was significant and occurred faster in patients using CS compared with the placebo, and this was observed as early as the sixth month of therapy. The NNT was found to be 8 (95\% CI 5-17), and no adverse event was reported. No significant effect on joint space narrowing was shown in a small sample-sized study with the use of GH. ${ }^{[74]}$ In another trial with LOE IIb, GS administration delayed the development of OA when compared with placebo in rats and decreased nociception. The authors reported that modification of chondrocyte metabolism might possibly have occurred by increasing the inhibition of the p38 kinase and the c-Jun $\mathrm{N}$ terminal kinase (JNK) or by increasing the release of an extracellular signal-related kinase (ERK). ${ }^{[75]}$ In another RCT (LOE Ib), cartilage turnover was evaluated, and patients on a quadriceps strengthening exercise program for 12 weeks were given either GS $1500 \mathrm{mg} /$ day, ibuprofen $1200 \mathrm{mg} /$ day, or placebo. A significant decrease in the serum level of cartilage oligometric protein (COMP) was determined in the patients taking GS. ${ }^{[76]}$ According to the results of a two-year follow-up study in which the effects of GH at a dose of $1500 \mathrm{mg} /$ day, CS $1200 \mathrm{mg} /$ day, celecoxib $200 \mathrm{mg} /$ day and placebo were compared, no superiority on the WOMAC pain scores was found in GS and CS users compared with celecoxib and the placebo (LOE Ib). ${ }^{[7]}$ In a five-year observational study, total knee replacement (TKR) was found to be less frequent among patients who had taken GS for at least 12 months compared with placebo. ${ }^{[78]}$ It should be kept in mind, however, that there are various factors which would affect the indication for TKR. As one can see, there is still much controversy regarding the efficacy of these molecules. 
Although there is no evidence concerning the provocation of diabetes mellitus or asthma with the consumption of glucosamines, precaution should be taken if the drug is used in high risk patients. An MA evaluating this issue was published in 2011 based on 11 trials (six RCTs and five prospective trials). ${ }^{[79]}$ A significant affect of glucosamines on glucose metabolism was shown in two RCTs. In several trials performed in obese patients, an affect was found on glucose metabolism while no affect was found in patients with diabetes mellitus. However, the formulations of the glucosamines were not mentioned, and administration was heterogenous (single or divided daily doses). The types of laboratory tests used for glucose metabolism were also not identical. Thus, further investigation is required. It should not be ignored that these molecules might provoke latent diabetes.

Glucosamines are also present in combinations that include other nutraceuticals in the market. According to a study performed in Italy, the amount and quality of the CS in these nutraceuticals varied. The authors emphasized that the health authority did not have strict regulations regarding manufacturers and controllers. ${ }^{[80]}$ This is, of course, not only a problem of Italy, but also of our country beside many others. This controversial proposition consisting of heterogenous trials was moderately supported by our experts (SOR 87.3\%; 95\% CI 80-95).

17. Administration of weak opioids or narcotic analgesics can be considered for patients with knee $O A$ who are resistant to or have contraindications for treatment with other pharmacologic agents. Treatment with non-pharmacologic modalities should be continued in these patients, and appropriate surgical options should be considered.

Treatment with opioids was recommended in almost all guidelines, including the 2008 OARSI recommendations. ${ }^{[2-5]}$ In an MA, the effect size of opioid treatment on pain and functional scores were reported as 0.78 (95\% CI $0.59-0.98)$ and 0.31 (95\% CI 0.24 0.39), respectively (LOE Ia). ${ }^{[81]}$ However, the trials were heterogenous with respect to methods and formulations in general. Nausea, constipation, sleep disturbance, dizziness, and vomiting are widely encountered adverse effects associated with opioid therapy, and these are the major causes for the discontinuation of the drug. There is no data concerning the long-term use of these drugs, especially related to dependence. For patients with moderate to severe pain, a significant reduction in pain and improvement in function might be achieved by the administration of tramadol once a day (LOE Ia). ${ }^{[82]}$ In a Cochrane review published in 2009, the advantages and disadvantages of opioid therapy (oral or transdermal) were compared versus placebo in patients with knee or hip OA (LOE Ia). Various kinds of opioid formulations were superior when compared with the placebo, but there were no differences between the two types of opioid therapy. ${ }^{[83]}$ The authors concluded that non-tramadol opioids had significant low to moderate benefits but that significant adverse effects also existed. They suggested that these formulations should not be used, even in cases suffering from severe pain. Weak opioids, such as tramadol, tramadol/paracetamol, codeine, and propoxyphen, should be preferred initially in resistant cases in which other types of treatments could not be applied. The stronger opioids, such as oxymorphone, oxycodone, phentanyl, and morphine sulphate, should be reserved for extraordinary conditions. The SOR was moderate (86.8\%, 95\% CI 80-93).

\section{Surgical Treatment}

18. Osteotomy can be applied in middle-aged, active, unicompartmental knee $O A$ patients with malalignment for the aim of biomechanical correction.

Based on a Cochrane SR, the authors mentioned some beneficial effects of high tibial osteotomy (HTO) on pain and function, despite there being no study which has compared the efficacy and safety of an osteotomy with a placebo or conservative treatment in unicompartmental knee OA (LOE IIa). ${ }^{[84]}$ It is difficult to compare and evaluate the results of studies concerning this procedure since there are various techniques used for a high tibial osteotomy. In another SR, unicompartmental knee arthroplasty (UKA) was compared with HTO and TKR. ${ }^{[85]}$ The results were found to be similar witih respect to function, but complications, such as deep venous thrombosis, were reported less frequently after UKA (not statistically significant), and revision rates were lower when compared with HTO. In brief, HTO and UKA can be accepted as surgical options for relatively young patients with involvement of the medial compartment, but the results are still controversial. There were no comparative trials with conservative treatments. The different surgical techniques used in the trials made a comparison difficult. Selecting the right patient and taking him/her expectations into account are thought to be important for positive outcome. It was reported that only a small number of patients with knee OA could be 
described as right candidates for this type of surgical approach (being 60-65 years old, moderately active, non-obese, having 5-10 degrees of varus malalignment, with no instability and no limitation in range of motion and with moderate unicompartmental involvement). ${ }^{[86]}$ The subject is still a matter of discussion, and more comprehensive studies are required. This proposition was supported moderately by the committee (SOR 86.9\%, 95\% CI 80-94).

19. Total knee replacement should be considered for patients with advanced knee $\mathrm{OA}$ who have resistant pain to pharmacologic and non-pharmacologic treatments and impaired quality of life. Not only the radiologic images but also the degree of pain and functional limitation of patients should be taken into consideration during the course of decision for surgery.

Total knee replacement was recommended in almost all guidelines for the management of the patients with advanced knee OA. Varying degrees of difference in pain relief and improvement in the function and quality of life have been reported. The cumulative rate of revision surgery was estimated to be $10 \%$ in several trials. ${ }^{[87,88]}$ Limitations in function, low mental scores, and comorbidities were reported as negative factors which determined the outcome for patients who underwent TKR. ${ }^{[89]}$ Total knee replacment was found to be cost-effective with respect to life-long expenses and quality of life and was more expensive and less efficient when performed in small centers, according to a study from the United States. ${ }^{[90]}$ The SOR was found to be 89.3\% (95\% CI 84-95).

In summary, an exact cure for knee $\mathrm{OA}$ is not possible yet. Preserving and/or improving the structure and function of joints along with providing symptom relief are the main targets in the management of knee OA with various treatment modalities. In this study, scientific evidence was reviewed and with contribution of experts in the field, evidence-based recommendations for the management of knee OA were developed for the first time in our country. The recommendations should be updated regularly according to new evidences and insights. We hope that physicians who are interested in knee OA will benefit from this report in their daily clinical practice.

\section{Acknowledgement}

We are grateful to Prof. Weiya Zhang, $\mathrm{PhD}$, for his scientific and moral support along with his expertise regarding methodology.

\section{Declaration of conflicting interests}

The authors declared no conflicts of interest with respect to the authorship and/or publication of this article.

\section{Funding}

The authors received no financial support for the research and/or authorship of this article.

\section{REFERENCES}

1. Kaçar C, Gilgil E, Urhan S, Arikan V, Dündar U, Oksüz $\mathrm{MC}$, et al. The prevalence of symptomatic knee and distal interphalangeal joint osteoarthritis in the urban population of Antalya, Turkey. Rheumatol Int 2005;25:201-4.

2. Zhang W, Moskowitz RW, Nuki G, Abramson S, Altman $\mathrm{RD}$, Arden $\mathrm{N}$, et al. OARSI recommendations for the management of hip and knee osteoarthritis, Part II: OARSI evidence-based, expert consensus guidelines. Osteoarthritis Cartilage 2008;16:137-62.

3. Jordan KM, Arden NK, Doherty M, Bannwarth B, Bijlsma JW, Dieppe P, et al. EULAR Recommendations 2003: an evidence based approach to the management of knee osteoarthritis: Report of a Task Force of the Standing Committee for International Clinical Studies Including Therapeutic Trials (ESCISIT). Ann Rheum Dis 2003;62:1145-55.

4. Conaghan PG, Dickson J, Grant RL; Guideline Development Group. Care and management of osteoarthritis in adults: summary of NICE guidance. BMJ 2008;336:502-3.

5. American Academy of Orthopaedic Surgeons Clinical Practice Guideline on the treatment of Osteoarthritis of the Knee(nonarthroplasty). Rosemaont (IL): American Academy of Orthopaedic Surgeons; 2008.

6. Zhang W, Nuki G, Moskowitz RW, Abramson S, Altman $\mathrm{RD}$, Arden NK, et al. OARSI recommendations for the management of hip and knee osteoarthritis: part III: Changes in evidence following systematic cumulative update of research published through January 2009. Osteoarthritis Cartilage 2010;18:476-99.

7. Shekelle PG, Woolf SH, Eccles M, Grimshaw J. Clinical guidelines: developing guidelines. BMJ 1999;318:593-6.

8. Oxman AD, Guyatt GH. Validation of an index of the quality of review articles. J Clin Epidemiol 1991;44:1271-8.

9. Jadad AR, Moore RA, Carroll D, Jenkinson C, Reynolds DJ, Gavaghan DJ, et al. Assessing the quality of reports of randomized clinical trials: is blinding necessary? Control Clin Trials 1996;17:1-12.

10. Zhang W, Moskowitz RW, Nuki G, Abramson S, Altman $\mathrm{RD}$, Arden $\mathrm{N}$, et al. OARSI recommendations for the management of hip and knee osteoarthritis, part I: critical appraisal of existing treatment guidelines and systematic review of current research evidence. Osteoarthritis Cartilage 2007;15:981-1000.

11. Cook RJ, Sackett DL. The number needed to treat: a clinically useful measure of treatment effect. BMJ 1995;310:452-4. 
12. Bezalel T, Carmeli E, Katz-Leurer M. The effect of a group education programme on pain and function through knowledge acquisition and home-based exercise among patients with knee osteoarthritis: a parallel randomised single-blind clinical trial. Physiotherapy 2010;96:137-43.

13. Vrezas I, Elsner G, Bolm-Audorff U, Abolmaali N, Seidler A. Case-control study of knee osteoarthritis and lifestyle factors considering their interaction with physical workload. Int Arch Occup Environ Health 2010;83:291-300.

14. Riecke BF, Christensen R, Christensen P, Leeds AR, Boesen M, Lohmander LS, et al. Comparing two lowenergy diets for the treatment of knee osteoarthritis symptoms in obese patients: a pragmatic randomized clinical trial. Osteoarthritis Cartilage 2010;18:746-54.

15. Bliddal H, Leeds AR, Stigsgaard L, Astrup A, Christensen R. Weight loss as treatment for knee osteoarthritis symptoms in obese patients: 1-year results from a randomised controlled trial. Ann Rheum Dis 2011;70:1798-803.

16. Klussmann A, Gebhardt $H$, Nübling $M$, Liebers $F$, Quirós Perea E, Cordier W, et al. Individual and occupational risk factors for knee osteoarthritis: results of a case-control study in Germany. Arthritis Res Ther 2010;12:R88.

17. Pisters MF, Veenhof C, Schellevis FG, De Bakker DH, Dekker J. Long-term effectiveness of exercise therapy in patients with osteoarthritis of the hip or knee: a randomized controlled trial comparing two different physical therapy interventions. Osteoarthritis Cartilage 2010;18:1019-26.

18. Farr JN, Going SB, McKnight PE, Kasle S, Cussler EC, Cornett M. Progressive resistance training improves overall physical activity levels in patients with early osteoarthritis of the knee: a randomized controlled trial. Phys Ther 2010;90:356-66.

19. Wang C, Schmid CH, Hibberd PL, Kalish R, Roubenoff $\mathrm{R}$, Rones $\mathrm{R}$, et al. Tai Chi is effective in treating knee osteoarthritis: a randomized controlled trial. Arthritis Rheum 2009;61:1545-53.

20. Gill SD, McBurney H, Schulz DL. Land-based versus pool-based exercise for people awaiting joint replacement surgery of the hip or knee: results of a randomized controlled trial. Arch Phys Med Rehabil 2009;90:388-94.

21. Jan MH, Lin CH, Lin YF, Lin JJ, Lin DH. Effects of weightbearing versus nonweight-bearing exercise on function, walking speed, and position sense in participants with knee osteoarthritis: a randomized controlled trial. Arch Phys Med Rehabil 2009;90:897-904.

22. Jenkinson intervention CM, Doherty M, Avery AJ, Read A, Taylor MA, Sach TH, et al. Effects of dietary and quadriceps strengthening exercises on pain and function in overweight people with knee pain: randomised controlled trial. BMJ 2009;339:b3170.

23. Yakut E, Yağlı VN, Akdoğan A, Kiraz S. Diz osteoartriti olan hastalarda Pilates egzersizlerinin rolü: bir pilot çalışma. Fizyoterapi Rehabilitasyon 2006;17:51-60.
24. Lin DH, Lin YF, Chai HM, Han YC, Jan MH. Comparison of proprioceptive functions between computerized proprioception facilitation exercise and closed kinetic chain exercise in patients with knee osteoarthritis. Clin Rheumatol 2007;26:520-8.

25. Karakuş D, Ersöz M, Eser F, Karaoğlan B, Kurtaran A. Diz osteoartriti olgularında konsantrik kuadriseps-hamstring ve konsantrik-eksantrik kuadriseps izokinetik egzersiz programlarının ağrı, fonksiyonel kapasite ve kuadriseps gücüne etkisi. Turk J Phys Med Rehab 2003;49:3-7.

26. Sallı A, Uğurlu H, Emlik D. Diz osteoartritinde konsantrik, kombine konsantrik-eksantrik ve izometrik egzersizlerin semptomlar ve fonksiyonel kapasite üzerine etkinliğinin karşılaştırılması. Turk J Phys Med Rehab 2006;52:61-7.

27. Jones A, Silva PG, Silva AC, Colucci M, Tuffanin A, Jardim JR, et al. Impact of cane use on pain, function, general health and energy expenditure during gait in patients with knee osteoarthritis: a randomised controlled trial. Ann Rheum Dis 2012;71:172-9.

28. Beaudreuil J, Bendaya S, Faucher M, Coudeyre E, Ribinik $\mathrm{P}$, Revel $\mathrm{M}$, et al. Clinical practice guidelines for rest orthosis, knee sleeves, and unloading knee braces in knee osteoarthritis. Joint Bone Spine 2009;76:629-36.

29. Kozakçıŏlu M, Akı S, Karan A, Aksoy C, Eskiyurt N, Berker E. Patella femoral eklem osteoartrit tedavisinde farklı bir yaklaşım: Patellanın bandajlanması Turk J Phys Med Rehab 1997;11:168-70.

30. Koca B, Öz B, Ölmez N, Memiş A. Effect of lateral wedge shoe insoles on pain and function in patients with knee osteoarthritis. Turk J Phys Med Rehab 2009;55:158-62.

31. van Raaij TM, Reijman M, Brouwer RW, Bierma-Zeinstra SM, Verhaar JA. Medial knee osteoarthritis treated by insoles or braces: a randomized trial. Clin Orthop Relat Res 2010;468:1926-32.

32. Gürer G, Şendur OF, Ay C. Diz osteoartrtritli hastalarda fizik tedavinin ağrı ve günlük yaşam aktivitesine etkileri. Rheumatism 2005;20:33-7.

33. Seçkin U, Çakar E, Özdemir B, Kıralp MZ, Dursun H. Comparison of effects of combined physical therapy program and exercise on corrupted balance functions in patients with knee bilateral osteoarthritis. Rheumatism 2008;23:9-13.

34. Rutjes AW, Nüesch E, Sterchi R, Kalichman L, Hendriks E, Osiri M, et al. Transcutaneous electrostimulation for osteoarthritis of the knee. Cochrane Database Syst Rev 2009; CD002823.

35. Altay F, Durmuş D, Canturk F. Effects of TENS on pain, disability, quality of life and depression in patients with knee osteoarthritis. Turk J Rheumatol 2010;25:116-21.

36. Kitay GS, Koren MJ, Helfet DL, Parides MK, Markenson JA. Efficacy of combined local mechanical vibrations, continuous passive motion and thermotherapy in the management of osteoarthritis of the knee. Osteoarthritis Cartilage 2009; 17:1269-74.

37. Rutjes AW, Nüesch E, Sterchi R, Jüni P. Therapeutic ultrasound for osteoarthritis of the knee or hip. Cochrane Database Syst Rev 2010;CD003132. 
38. Loyola-Sánchez A, Richardson J, MacIntyre NJ. Efficacy of ultrasound therapy for the management of knee osteoarthritis: a systematic review with meta-analysis. Osteoarthritis Cartilage 2010;18:1117-26.

39. Kalpakçıŏlu BA, Çakmak B, Bahadır C. Comparison of ultrasound and short wave diathermy terapy in knee osteoarthritis. Turk J Phys Med Rehab 2006;52:168-73.

40. Ozgönenel L, Aytekin E, Durmuşoglu G. A double-blind trial of clinical effects of therapeutic ultrasound in knee osteoarthritis. Ultrasound Med Biol 2009;35:44-9.

41. Külcü Geler D, Gülşen G, Altınok EÇ. Short term efficacy of pulsed electromagnetic field therapy on pain and functional level in knee osteoarthritis: A randomised controlled study. Turk J Rheumatol 2009;24:144-8.

42. Vavken P, Arrich F, Schuhfried O, Dorotka R. Effectiveness of pulsed electromagnetic field therapy in the management of osteoarthritis of the knee: a meta-analysis of randomized controlled trials. J Rehabil Med 2009;41:406-11.

43. Ozgüçlü E, Cetin A, Cetin M, Calp E. Additional effect of pulsed electromagnetic field therapy on knee osteoarthritis treatment: a randomized, placebo-controlled study. Clin Rheumatol 2010;29:927-31.

44. Madenci E, Gürsoy S, Büyükbese IA. Diz osteoartritli olgularda iyontofores ve fonoferez yöntemlerinin etkinliklerinin ve yaşam kalitesine olan etkilerinin karşılaştırılması. Romatoloji ve Tıbbi Rehabilitasyon Dergisi 2002;13:98-101.

45. Yıldırım K, Karatay S, Şişecioğlu M, Uğur M, Şenel K. $\mathrm{Diz}$ osteoartritli hastaların tedavisinde iyontoforez ve fonoferez. Turk J Phys Med Rehab 2004;50:13-6.

46. Kocaman Ö, Koyuncu H, Dinç A, Toros H, Karamehmetoğlu ŞS. The comparison of the effects of electrical stimulation and exercise in the treatment of knee osteoarthritis. Turk J Phys Med Rehab 2008;54:54-8.

47. Naragi M, Aksoy C, Ketenci A, Karan A. Diz osteoartritinin rehabilitasyonunda nöromuskuler elektrik stimülasyon ve ev egzersiz programının kantitatif kas güçlendirilmesi ve fonksiyonel iyileşme yönünden karşılaştırılması. Turk J Phys Med Rehab 1998;1:58-61.

48. Birtane M, Pekindil Y, Sarıkaya A, Kokino S. Isometric exercise on quadriceps muscle by $99 \mathrm{~m}$ Tc Sestamibi scintigraphy. Turk J Phys Med Rehab 2001;47:20-7.

49. Monaghan B, Caulfield B, O’Mathúna DP. Surface neuromuscular electrical stimulation for quadriceps strengthening pre and post total knee replacement. Cochrane Database Syst Rev 2010;CD007177.

50. Harzy T, Ghani N, Akasbi N, Bono W, Nejjari C. Short- and long-term therapeutic effects of thermal mineral waters in knee osteoarthritis: a systematic review of randomized controlled trials. Clin Rheumatol 2009;28:501-7.

51. Forestier R, Desfour H, Tessier JM, Françon A, Foote AM, Genty C, et al. Spa therapy in the treatment of knee osteoarthritis: a large randomised multicentre trial. Ann Rheum Dis 2010;69:660-5.

52. Kiliçoğlu O, Dönmez A, Karagülle Z, Erdoğan N, Akalan E, Temelli Y. Effect of balneotherapy on temporospatial gait characteristics of patients with osteoarthritis of the knee. Rheumatol Int 2010;30:739-47.
53. Manheimer E, Cheng K, Linde K, Lao L, Yoo J, Wieland $\mathrm{S}$, et al. Acupuncture for peripheral joint osteoarthritis. Cochrane Database Syst Rev 2010;CD001977.

54. Hawker GA, Mian S, Bednis K, Stanaitis I. Osteoarthritis year 2010 in review: non-pharmacologic therapy. Osteoarthritis Cartilage 2011;19:366-74.

55. Rahme E, Barkun A, Nedjar H, Gaugris S, Watson D. Hospitalizations for upper and lower GI events associated with traditional NSAIDs and acetaminophen among the elderly in Quebec, Canada. Am J Gastroenterol 2008; 103:872-82.

56. Curhan GC, Knight EL, Rosner B, Hankinson SE, Stampfer MJ. Lifetime nonnarcotic analgesic use and decline in renal function in women. Arch Intern Med 2004;164:1519-24.

57. Benson M, Marangou A, Russo MA, Durocher J, Collaku A, Starkey YY. Patient preference for sustained-release versus standard paracetamol (acetaminophen): a multicentre, randomized, open-label, two-way crossover study in subjects with knee osteoarthritis. J Int Med Res 2009;37:1321-35.

58. Borman P, Kutsal YG. Diz osteoartritli hastaların tedavisinde diflünisal etkinliği. Fiziksel Tip 1999;2:25-7.

59. Kim J, Lee EY, Koh EM, Cha HS, Yoo B, Lee CK, et al. Comparative clinical trial of S-adenosylmethionine versus nabumetone for the treatment of knee osteoarthritis: an 8-week, multicenter, randomized, double-blind, doubledummy, Phase IV study in Korean patients. Clin Ther 2009;31:2860-72.

60. Schnitzer TJ, Kivitz A, Frayssinet H, Duquesroix B. Efficacy and safety of naproxcinod in the treatment of patients with osteoarthritis of the knee: a 13-week prospective, randomized, multicenter study. Osteoarthritis Cartilage 2010;18:629-39.

61. de Boer TN, Huisman AM, Polak AA, Niehoff AG, van Rinsum AC, Saris D, et al. The chondroprotective effect of selective COX-2 inhibition in osteoarthritis: ex vivo evaluation of human cartilage tissue after in vivo treatment. Osteoarthritis Cartilage 2009;17:482-8.

62. Bjordal JM, Klovning A, Ljunggren AE, Slørdal L. Shortterm efficacy of pharmacotherapeutic interventions in osteoarthritic knee pain: A meta-analysis of randomised placebo-controlled trials. Eur J Pain 2007;11:125-38.

63. Chevalier X, Jerosch J, Goupille P, van Dijk N, Luyten FP, Scott DL, et al. Single, intra-articular treatment with 6 ml hylan G-F 20 in patients with symptomatic primary osteoarthritis of the knee: a randomised, multicentre, double-blind, placebo controlled trial. Ann Rheum Dis 2010;69:113-9.

64. Shimizu M, Higuchi H, Takagishi K, Shinozaki T, Kobayashi T. Clinical and biochemical characteristics after intra-articular injection for the treatment of osteoarthritis of the knee: prospective randomized study of sodium hyaluronate and corticosteroid. J Orthop Sci 2010;15:51-6.

65. Jørgensen A, Stengaard-Pedersen K, Simonsen O, PfeifferJensen $\mathrm{M}$, Eriksen $\mathrm{C}$, Bliddal $\mathrm{H}$, et al. Intra-articular hyaluronan is without clinical effect in knee osteoarthritis: 
a multicentre, randomised, placebo-controlled, doubleblind study of 337 patients followed for 1 year. Ann Rheum Dis 2010;69:1097-102.

66. Bütün B, Kacar C, Evcik D. Intraarticular injection of sodium hyaluronate in the treatment of knee osteoarthritis. Rheumatism 2002;17:31-8.

67. Sezgin M, Demirel AÇ, Ortancıl Ö, Karaca C, Çınar C, Çakçı A. The efficacy of hyaluronan treatment on the knee osteoarthritis with effusion: one year placebo controlled trial. Rheumatism 2003;18:133-9.

68. Diracoglu D, Vural M, Baskent A, Dikici F, Aksoy C. The effect of viscosupplementation on neuromuscular control of the knee in patients with osteoarthritis. J Back Musculoskelet Rehabil 2009;22:1-9.

69. Persiani S, Rotini R, Trisolino G, Rovati LC, Locatelli M, Paganini D, et al. Synovial and plasma glucosamine concentrations in osteoarthritic patients following oral crystalline glucosamine sulphate at therapeutic dose. Osteoarthritis Cartilage 2007;15:764-72.

70. Towheed TE, Maxwell L, Anastassiades TP, Shea B, Houpt J, Robinson V, et al. Glucosamine therapy for treating osteoarthritis. Cochrane Database Syst Rev 2005;CD002946.

71. Lee YH, Woo JH, Choi SJ, Ji JD, Song GG. Effect of glucosamine or chondroitin sulfate on the osteoarthritis progression: a meta-analysis. Rheumatol Int 2010;30:357-63.

72. Hochberg MC. Structure-modifying effects of chondroitin sulfate in knee osteoarthritis: an updated meta-analysis of randomized placebo-controlled trials of 2-year duration. Osteoarthritis Cartilage 2010;18 Suppl 1:S28-31.

73. Kahan A, Uebelhart D, De Vathaire F, Delmas PD, Reginster JY. Long-term effects of chondroitins 4 and 6 sulfate on knee osteoarthritis: the study on osteoarthritis progression prevention, a two-year, randomized, double-blind, placebo-controlled trial. Arthritis Rheum 2009;60:524-33.

74. Sawitzke AD, Shi H, Finco MF, Dunlop DD, Bingham CO 3rd, Harris CL, et al. The effect of glucosamine and/or chondroitin sulfate on the progression of knee osteoarthritis: a report from the glucosamine/ chondroitin arthritis intervention trial. Arthritis Rheum 2008;58:3183-91.

75. Wen ZH, Tang CC, Chang YC, Huang SY, Hsieh SP, Lee $\mathrm{CH}$, et al. Glucosamine sulfate reduces experimental osteoarthritis and nociception in rats: association with changes of mitogen-activated protein kinase in chondrocytes. Osteoarthritis Cartilage 2010;18:1192-202.

76. Petersen SG, Saxne T, Heinegard D, Hansen M, Holm L, Koskinen S, et al. Glucosamine but not ibuprofen alters cartilage turnover in osteoarthritis patients in response to physical training. Osteoarthritis Cartilage 2010;18:34-40.

77. Sawitzke AD, Shi H, Finco MF, Dunlop DD, Harris
CL, Singer NG, et al. Clinical efficacy and safety of glucosamine, chondroitin sulphate, their combination, celecoxib or placebo taken to treat osteoarthritis of the knee: 2-year results from GAIT. Ann Rheum Dis 2010;69:1459-64.

78. Bruyere O, Pavelka K, Rovati LC, Gatterová J, Giacovelli $\mathrm{G}$, Olejarová $\mathrm{M}$, et al. Total joint replacement after glucosamine sulphate treatment in knee osteoarthritis: results of a mean 8-year observation of patients from two previous 3-year, randomised, placebo-controlled trials. Osteoarthritis Cartilage 2008;16:254-60.

79. Dostrovsky NR, Towheed TE, Hudson RW, Anastassiades TP. The effect of glucosamine on glucose metabolism in humans: a systematic review of the literature. Osteoarthritis Cartilage 2011;19:375-80.

80. Volpi N. Quality of different chondroitin sulfate preparations in relation to their therapeutic activity. J Pharm Pharmacol 2009;61:1271-80.

81. Avouac J, Gossec L, Dougados M. Efficacy and safety of opioids for osteoarthritis: a meta-analysis of randomized controlled trials. Osteoarthritis Cartilage 2007;15:957-65.

82. Kean WF, Bouchard S, Roderich Gossen E. Women with pain due to osteoarthritis: the efficacy and safety of a oncedaily formulation of tramadol. Pain Med 2009;10:1001-11.

83. Nüesch E, Rutjes AW, Husni E, Welch V, Jüni P. Oral or transdermal opioids for osteoarthritis of the knee or hip. Cochrane Database Syst Rev 2009;CD003115.

84. Brouwer RW, Raaij van TM, Bierma-Zeinstra SM, Verhagen AP, Jakma TS, Verhaar JA. Osteotomy for treating knee osteoarthritis. Cochrane Database Syst Rev 2007;CD004019.

85. Griffin T, Rowden N, Morgan D, Atkinson R, Woodruff P, Maddern G. Unicompartmental knee arthroplasty for the treatment of unicompartmental osteoarthritis: a systematic study. ANZ J Surg 2007;77:214-21.

86. Dettoni F, Bonasia DE, Castoldi F, Bruzzone M, Blonna D, Rossi R. High tibial osteotomy versus unicompartmental knee arthroplasty for medial compartment arthrosis of the knee: a review of the literature. Iowa Orthop J 2010;30:131-40.

87. Rand JA, Trousdale RT, Ilstrup DM, Harmsen WS. Factors affecting the durability of primary total knee prostheses. J Bone Joint Surg [Am] 2003;85-A:259-65.

88. Ethgen $\mathrm{O}$, Bruyère $\mathrm{O}$, Richy $\mathrm{F}$, Dardennes $\mathrm{C}$, Reginster JY. Health-related quality of life in total hip and total knee arthroplasty. A qualitative and systematic review of the literature. J Bone Joint Surg [Am] 2004;86:963-74.

89. Lingard EA, Katz JN, Wright EA, Sledge CB; Kinemax Outcomes Group. Predicting the outcome of total knee arthroplasty. J Bone Joint Surg [Am] 2004;86:2179-86.

90. Losina E, Walensky RP, Kessler CL, Emrani PS, Reichmann WM, Wright EA, et al. Cost-effectiveness of total knee arthroplasty in the United States: patient risk and hospital volume. Arch Intern Med 2009;169:1113-21. 